\title{
DIMENSI KEPERDATAAN DALAM PERLINDUNGAN HUKUM ATAS ANAK JALANAN DI YOGYAKARTA
}

\author{
Asram A.T.Jadda \\ Fakultas Hukum, \\ Universitas Muhammadiyah Parepare, Jalan Jenderal Ahmad Yani KM 6 Kota Parepare \\ Kode Pos 91113, Telpon : 0421-22757/Fax 0421-2554 Sulawesi Selatan Indonesia \\ Email: Asram 77@yahoo.co.id/081230293103
}

\begin{abstract}
Abstrack: The research on "Privat Dimension Of Legal Protection For The Street Children In Yogyakarta" is the empiris legal research, aiming to investigate about privat dimension of legal protection for street children in Yogyakarta. Primary and secondary data were obtained from field research and library research. The instrumen collecting data used interview, observation, and document study. The data were then analyzed qualitatively. The research results indicate that the street children in Yogyakarta which have fluctuation mobile still haven't gotten protection measure yet, ecspecially their identity, health, education, shelter, and jobs. Culture factors of Yogyakarta's communities who still regard children as parent's "asset", the quality of education level which still low, and implementation of legislation about children protection which is irrational, irresponsible and usless influence the implementation of the street children. Protection for the street children in Yogyakarta can be done well if the parties who have a role about children protection can cooperate and coordinate well. The parties are : Children Protection Institution (LPA) DIY, Indonesian Family Planning Program Association (PKBI) DIY, Anak Mandiri Boarding House, and Legal Aid Institution (LBH) Yogyakarta. The efforts doing are assistance, founding, until reunification the children to their families needs good support from families, comunities, government, and the children too; so their rights which are protected by Convention On The Rights Of The Child on 1989 (already ratificated by KEPPRES No. 36 on 1990) can be protected.
\end{abstract}

Keyword : Privat dimension, Legal Protection, The Street Children.

Abstrak: Penelitian tentang "Dimensi Privat Perlindungan Hukum untuk Anak Jalanan di Yogyakarta" adalah penelitian hukum empiris, yang bertujuan untuk menyelidiki tentang dimensi privasi perlindungan hukum bagi anak-anak jalanan di Yogyakarta. Data primer dan data sekunder diperoleh dari penelitian lapangan dan penelitian kepustakaan. Instrumen pengumpulan data menggunakan wawancara, observasi, dan studi dokumen. Data tersebut kemudian dianalisis secara kualitatif. Hasil penelitian menunjukkan bahwa anak jalanan di Yogyakarta yang memiliki fluktuasi mobile masih belum mendapat perlindungan, terutama identitas, kesehatan, pendidikan, tempat tinggal, dan pekerjaan mereka. Faktor budaya masyarakat Yogyakarta yang masih menganggap anak sebagai "aset" orang tua, kualitas tingkat pendidikan yang masih rendah, dan penerapan peraturan tentang perlindungan anak yang tidak masuk akal, tidak bertanggung jawab dan tidak berpengaruh mempengaruhi pelaksanaan anak jalanan. Perlindungan bagi anak-anak jalanan di Yogyakarta dapat 
dilakukan dengan baik jika pihak-pihak yang memiliki peran perlindungan anak dapat bekerja sama dan berkoordinasi dengan baik. Para pihak adalah: Lembaga Perlindungan Anak (LPA) DIY, Asosiasi Program Keluarga Berencana Indonesia (PKBI) DIY, Asrama Anak Mandiri, dan Lembaga Bantuan Hukum (LBH) Yogyakarta. Upaya yang dilakukan adalah bantuan, pendirian, sampai penyatuan kembali anak-anak ke keluarga mereka memerlukan dukungan baik dari keluarga, masyarakat, pemerintah, dan anak-anak juga; sehingga hak-hak mereka yang dilindungi oleh Konvensi Hak Anak pada tahun 1989 (sudah diratifikasi oleh KEPPRES No. 36 pada tahun 1990) dapat dilindungi.

Kata Kunci: Dimensi Privat, perlindungan Hukum, Anak jalanan

\section{LATAR BELAKANG}

Bangsa Indonesia yang dalam proses membangun masih terus mengupayakan pembentukan dan pembinaan suatu tata penghidupan serta kepribadiannya secara terus menerus dari generasi ke generasi. Anak mempunyai peran yang cukup penting di dalam proses pembangunan. Anak adalah tunas, potensi dan generasi muda penerus cita-cita perjuangan bangsa yang dasar-dasarnya telah diletakkan oleh generasi sebelumnya, memiliki peran yang strategis dan mempunyai ciri dan sifat khusus yang menjamin kelangsungan eksistensi bangsa dan negara pada masa depan. Anak-anak membutuhkan perlindungan serta perawatan khusus termasuk perlindungan hukum sebelum maupun sesudah mereka dilahirkan, karena alasan fisik dan mental yang belum matang dan dewasa.

Tiap-tiap anak, sampai ia menjadi dewasa, tetap bernaung di bawah kekuasaan orang tua. Orang tua adalah orang yang paling bertanggung jawab dalam mengupayakan kesejahteraan, perlindungan, peningkatan kelangsungan hidup, dan mengoptimalkan tumbuh kembang anaknya. Kekuasaan dan tanggung jawab orang tua terhadap anak tersebut telah diatur secara jelas di dalam Buku Kesatu, Bab XIV tentang Kekuasaan Orang tua dan pasal 9 dan 10 Undangundang Nomor 4 Tahun 1979 tentang Kesejahteraan Anak. Keluarga adalah tempat pertama kali anak belajar mengenal aturan yang berlaku di lingkungan keluarga dan masyarakat. Di dalam proses belajar itu, anak tidak luput atau cenderung melakukan kesalahan namun demikian anak akan lebih mengetahui tindakantindakan yang bermanfaat dan tidak bermanfaat, patut atau tidak patut. Dengan meletakkan anak sebagai subjek hukum yang lahir dari proses sosialisasi berbagai nilai ke dalam perbuatan hukum secara substansial meliputi perbuatan hukum pidana maupun perbuatan hukum perdata, sehingga menjadi mata rantai yang tidak dapat dipisahkan. Oleh karena itu, perlindungan hukum anak mencakup dua (2) dimensi hukum, yaitu: 
Pertama, Dimensi hukum keperdataan, dimana Perlindungan dalam hal anak melakukan perbuatan melawan hukum (onrechtmatige daad), dimana orang tua dan wali yang bertanggung jawab terhadap perbuatan anak tersebut seperti yang diatur dalam Pasal 1367 KUH Perdata.

Kedua, Dimensi hukum pidana, dimana Perlindungan dalam hal tindak pidana (strafbaar feit) yang dilakukan oleh seseorang dan atau anak itu sendiri, baik sebagai korban kejahatan (victim) maupun sebagai pelaku kejahatan (kindermoore).

Indonesia dikenal sebagai negara hukum yang demokratis. Di dalam negara hukum, negara berada sederajat dengan individu, dan kekuasaan negara dibatasi oleh hak asasi manusia. Hak asasi manusia merupakan sesuatu yang inheren dalam diri setiap manusia dan tidak dapat dipisahkan, dikurangi, atau diambil begitu saja oleh negara, betapapun berpengaruhnya pemerintahan yang otoriter, betapapun dominannya mayoritas atau kuatnya pemerintahan militer. Di dalam negara hukum yang demokratis, hak-hak individu selalu dilindungi oleh undang-undang yang demokratis berasal dari rakyat. Perlindungan terhadap individu adalah tugas negara, dan perlindungan individu ini harus sama terhadap semua warga negara tanpa terkecuali, termasuk terhadap anak (equality before the law). Hak asasi anak merupakan bagian dari hak asasi manusia yang termuat dalam Undang-Undang Dasar Tahun 1945 dan Konvensi Perserikatan Bangsa-Bangsa tentang Hakhak Anak yaitu Deklarasi Hak Asasi Anak (Declarataion on the Rights of the Child 1989) yaitu telah diratifikasi melalui Keputusan Presiden Nomor 36 Tahun 1990 tentang Hak-hak Anak. Konvensi Hak Anak Tahun 1989 memuat empat (4) prinsip dasar hak-hak anak, yaitu: hak hidup, hak kelangsungan hidup / tumbuh kembang, kepentingan terbaik anak, dan hak partisipasi / mengemukakan pendapat.

Kenyataannya di dalam masyarakat masih terdapat anak-anak yang mengalami hambatan kesejahteraan rohani, jasmani, sosial dan ekonomi sehingga memerlukan pelayanan secara khusus seperti yang diatur dalam Undang-Undang Nomor 4 Tahun 1979 tentang Kesejahteraan Anak, yaitu: anak-anak yang tidak mampu, anakanak terlantar, anak-anak yang mengalami masalah kelakuan, anak-anak yang cacat rohani dan atau jasmani. Oleh karena itu, diperlukan dukungan kelembangaan dan peraturan perundang-undangan yang dapat menjamin pelaksanaan perlindungan terhadap hak-hak anak. Undang-undang Nomor 35 Tahun 2014 Tentang Pengganti Undang-undang Nomor 23 Tahun 2002 Tentang Perlindungan Anak menegaskan 
bahwa pertanggungjawaban orang tua, keluarga masyarakat, pemerintah dan negara merupakan rangkaian kegiatan yang dilaksanakan secara terus-menerus demi terlindunginya hak-hak anak. Perlindungan anak di dalam proses pembangunan nasional dilakukan sebagai bagian dari proses peningkatan kualitas manusia Indonesia seutuhnya dan masyarakat Indonesia seluruhnya, yaitu melalui Gerakan Nasional Perlindungan Anak. Prinsip dasar di dalam implementasi Gerakan Nasional Perlindungan Anak di Indonesia yaitu:

Pertama, Upaya yang dilakukan dalam pelaksanaan Gerakan Nasional Perlindungan Anak mengutamakan kepentingan terbaik bagi anak.

Kedua, Keberadaan anak sebagai subyek harus mendapat perhatian dan dihargai, namun hendaknya keberadaan mereka diletakkan dalam nuansa kebersamaan yang harmoni antar generasi.

Ketiga, Anak bukanlah individu yang berdiri sendiri, tetapi merupakan elemen yang menyatu dengan unsur lainnya dalam membentuk kesatuan keluarga, kelompok, warga masyarakat dan bangsa, bahkan warga dunia. Oleh karena itu, anak harus mendapat kesempatan membangun semangat kesetiakawanan sosial.

Keempat, Semua anak adalah insan sosial yang harus dihargai harkat dan

\section{4}

martabatnya sebagai individu yang sama dengan orang dewasa dan terakhir, Anak Indonesia berasal dari berbagai suku bangsa dengan latar belakang budaya lokal yang menyertainya. Hal ini harus dipandang suatu "nilai tambah" yang tidak banyak dimiliki bangsa lain. Oleh karena itu, perlu selalu mengutamakan jalinan semangat Bhineka Tunggal Ika diantara sesama anak Indonesia. ${ }^{1}$

Ada beberapa pihak yang memiliki peran di dalam perlindungan hukum anak khususnya anak jalanan yaitu pihak pemerintah antara lain: Dinas Kesehatan dan Kesejahteraan Sosial dan para aparat penegak hukum seperti pihak Kepolisian dan Peradilan yang menjalin kerjasama juga dengan rumah singgah-rumah singgah. Undang-Undang Nomor 35 Tahun 2014 tentang Perlindungan Anak menjelaskan bahwa dalam melakukan pembinaan, pengembangan, dan perlindungan anak (termasuk anak jalanan), maka perlu peran beberapa pihak, yaitu: Lembaga Perlindungan Anak (LPA), Lembaga Keagamaan, Lembaga Swadaya Masyarakat (LSM), Organisasi kem asyarakatan (termasuk LBH), Organisasi social, Dunia usaha, Media massa dan terakhir Lembaga pendidikan.

\footnotetext{
${ }^{1}$ (Sholeh Soeaidy dan Zulkhair, Dasar Hukum Perlindungan Anak, Novindo Jakarta: Pustaka Mandiri,2001,hlm 7-8
} 
Di Yogyakarta, salah satu kota besar di Indonesia, memiliki jumlah anak jalanan yang cukup besar karena mobilitasnya cukup cepat. Adapun anak jalanan dapat dikelompokkan menjadi dua macam yaitu:

Pertama, Anak Jalanan on the street / road Kategori anak jalanan on the street/road atau anak-anak yang ada di jalanan, hanya sesaat saja di jalanan, dan meliputi dua kelompok yaitu kelompok dari luar kota dan kelompok dari dalam kota.

Kedua, Anak Jalanan of the street / road Kategori anak jalanan of the street / road atau anak-anak yang tumbuh dari jalanan, seluruh waktunya dihabiskan di jalanan, tidak mempunyai rumah, dan jarang atau tidak pernah kontak dengan keluarganya ${ }^{2}$

Anak-anak jalanan sangat rentan terhadap masalah dan dalam keadaan tanpa pelindung, sewajarnya yang dimiliki anak pada umumnya, karena mereka tinggal di jalan (antara lain: jalan-jalan raya, terminal-terminal bus, stasiun-stasiun kereta api, pelantaran-pelantara pertokoan, pusat-pusat perbelanjaan, dan sebagainya). Anak-anak jalanan tersebut terperangkap dalam eksploitasi fisik yang diantaranya: pekerja / buruh anak dan pengemisan,

\footnotetext{
2 Tata Sudrajat, Anak Jalanan dan Masalah Seharihari Sampai Kebijaksanaan, Bandung: Yayasan Akatiga, 1984, hlm 151-152
}

maupun eksploitasi seksual seperti: prostitusi dan sodomi. Adapun masalah identitas seperti Akta Kelahiran bagi anak yang belum berumur 17 tahun, ataupun Kartu Tanda Penduduk (KTP) bagi anak yang berumur dari 17 tahun masih menjadi masalah penting bagi anak jalanan. Berdasarkan latar belakang masalah di atas maka dapat dirumuskan permasalahan yaitu bagaimanakah dimensi keperdataan dalam perlindungan hukum atas anak jalanan di Yogyakarta.

\section{METODE PENULISAN}

Penelitian ini merupakan penelitian hukum empiris. Penelitian hukum empiris ialah suatu penelitian yang mendasarkan atau mengkonsepkan hukum sebagai tingkah laku atau perilaku dan aksi. Penelitian hukum empiris meneliti suatu masalah, keadaan atau peristiwa dengan memberikan suatu penilaian secara menyeluruh, luas dan mendalam dari sudut pandang ilmu hukum, yang terdiri dari penelitian terhadap identifikasi hukum (tidak tertulis) dan penelitian terhadap efektivitas hukum. Data diperoleh secara langsung dari lapangan (data empiris) dan didukung dari bahan pustaka. Jadi, pada awalnya yang diteliti adalah data sekunder untuk kemudian dilanjutkan dengan 
penelitian terhadap data primer di lapangan. $^{3}$

Penelitian lapangan merupakan suatu penelitian yang dilakukan untuk memperoleh data primer dengan terjun langsung ke lapangan, yang dikumpulkan dengan cara wawancara pada pihak yang bersangkutan untuk memberikan keterangan sehingga didapatkan data yang valid. Dalam penelitian ini, data tersebut diperoleh dari: Lembaga Perlindungan Anak (LPA) DIY, Perkumpulan Keluarga Berencana Indonesia (PKBI) DIY, Rumah Singgah Anak Mandiri, Lembaga Bantuan Hukum (LBH) Yogyakarta, dan Organisasi anak jalanan di Yogyakarta atau Tim Advokasi Arus Bawah (TAABAH).

Responden dalam penelitian ini ialah organisasi anak jalanan di Yogyakarta (TAABAH). Narasumber dalam penelitian ini ialah LPA (Humas dan Staf Pelaksana Program), PKBI DIY (Koordinator Anak Jalanan dan Waria), Rumah Singgah Anak Mandiri (Ketua Umum dan anggota Dewan Pengurus), dan LBH Yogyakarta (Pimpinan / Direktur).

Alat pengumpulan data dalam penelitian ini meliputi wawancara dan observasi. Wawancara dilakukan untuk memperoleh data terhadap orang-orang

\footnotetext{
${ }^{3}$ Soerjono Soekanto, Pengantar Penelitian Hukum, Jakarta: Universitas Indonesia Press, 1984,hlm 5052.
}

yang dianggap mengetahui dan dimungkinkan diperoleh data yang berguna dan dapat dipertanggungjawabkan kebenarannya. Dalam hal ini, peneliti melakukan wawancara dengan pihak LPA ( Humas dan Staf Pelaksanaan Program ), PKBI (Koordinator Anak Jalanan dan Waria), Rumah Singgah Anak Mandiri (Ketua Umum dan anggota Dewan Pengurus), LBH Yogyakarta (Pimpinan/ Direktur), dan organisasi anak jalanan di Yogyakarta (TAABAH). Observasi dilakukan oleh peneliti dengan mengadakan pengamatan secara langsung terhadap obyek yang berkaitan dengan masalah yang diteliti, dengan tujuan untuk mendapatkan data yang menyeluruh dari perilaku manusia atau sekelompok manusia sebagaimana terjadi dalam kenyataannya dan mendapatkan deskripsi yang relatif lengkap mengenai kehidupan sosial dan salah satu aspeknya. ${ }^{4}$ Dalam hal ini, peneliti melakukan observasi terhadap organisasi anak jalanan di Yogyakarta (TAABAH) dan Rumah Singgah Anak Mandiri Yogyakarta selama kurang lebih satu (1) bulan.

Penelitian Kepustakaan dilakukan dengan memanfaatkan buku-buku, daftar atau table, literatur, dokumen, perundangundangan, dan sebagainya untuk memperoleh data sekunder yang 
menunjang kelengkapan penelitian. Data dalam penelitian ini diperoleh dari: bahan hukum primer yang terdiri beberapa peraturan perundang-undangan yang berkaitan dengan masalah yang diteliti tentang perlindungan anak; bahan hukum sekunder yang terdiri dari beberapa literatur yang memberi penjelasan tentang peraturan perundang-undangan tersebut; dan bahan hukum tersier terdiri dari beberapa kamus yang memberi penjelasan dan petunjuk terhadap peraturan perundang-undangan dan literatur tersebut.

Data yang telah diperoleh dari penelitian lapangan dan penelitian kepustakaan akan dianalisis secara kualitatif, maksudnya ialah tidak sematamata bertujuan untuk mengungkapkan kebenaran belaka akan tetapi untuk memahami kebenaran tersebut, sehingga menghasilkan data deskriptif-analitis yaitu apa yang dinyatakan oleh responden maupun narasumber, secara tertulis atau lisan dan juga perlakunya yang nyata di teliti dan dipelajari sebagai sesuatu yang utuh.

\section{PEMBAHASAN}

Kondisi anak jalanan di Yogyakarta memiliki mobilisasi yang terus berfluktuasi I naik turun dari waktu ke waktu baik, dilatarbelakangi oleh kondisi geografis dan sosiologis Yogyakarta yang strategis dan memiliki keragaman potensi. Jumlah anak jalanan perempuan baik anak kerja di jalan (A.K), anak hidup di jalan (A.H), dan anak keluarga jalanan (A.K.J), serta anak yang rentan ke jalan yang dilayani dalam program Japan Fund for Poverty Reduction-Asian Development Bank (JFPR-ADB) tahun 2004 yaitu sebagai berikut:

\begin{tabular}{|c|c|c|c|c|c|}
\hline \multirow{2}{*}{$\begin{array}{c}\text { Umu } \\
\text { r }\end{array}$} & \multicolumn{2}{|c|}{ Anak Jalanan } & \multicolumn{2}{c|}{ Anak Rentan } \\
\cline { 2 - 6 } & K & H. & A.K. & Ekono & $\begin{array}{c}\text { Life } \\
\text { styl } \\
\text { mi }\end{array}$ \\
\hline $\begin{array}{c}0-4 \\
\text { th }\end{array}$ & - & - & 1 & 24 & - \\
\hline $\begin{array}{c}5-9 \\
\text { th }\end{array}$ & 19 & 1 & 1 & 59 & 5 \\
\hline $\begin{array}{c}10- \\
14 \text { th }\end{array}$ & 18 & 4 & 4 & 83 & 10 \\
\hline $\begin{array}{c}15- \\
17 \text { th }\end{array}$ & 19 & 23 & 1 & 48 & 16 \\
\hline $\begin{array}{c}18- \\
21 \text { th }\end{array}$ & 19 & 57 & - & 45 & 41 \\
\hline $\begin{array}{c}<21 \\
\text { th }\end{array}$ & 8 & 17 & 1 & 32 & 16 \\
\hline Total & $\mathbf{8 3}$ & $\mathbf{1 0 2}$ & $\mathbf{8}$ & $\mathbf{2 9 1}$ & $\mathbf{8 8}$ \\
\hline Sumyyyy & & & & & \\
\hline
\end{tabular}

Sumber : HUMANA, 2004

Adapun jumlah anak dalam situasi khusus dan anak yang diluncurkan adalah sebagai berikut: 


\begin{tabular}{|c|c|c|c|}
\hline \multirow{2}{*}{$\begin{array}{c}\text { Umu } \\
\mathbf{r}\end{array}$} & \multicolumn{2}{|c|}{$\begin{array}{c}\text { Anak dalam } \\
\text { Situasi Khusus }\end{array}$} & \multirow{2}{*}{$\begin{array}{c}\text { Anak } \\
\text { diluncurk } \\
\text { an }\end{array}$} \\
\hline & $\begin{array}{c}\text { Bayi } \\
\text { seraha } \\
\mathbf{n}\end{array}$ & $\begin{array}{c}\text { Korban } \\
\text { Kekerasa } \\
\text { n Seks }\end{array}$ & \\
\hline $0-4$ th & 18 & 11 & - \\
\hline $5-9$ th & 3 & 30 & - \\
\hline $\begin{array}{c}10-14 \\
\text { th }\end{array}$ & & 33 & - \\
\hline $\begin{array}{c}15-17 \\
\text { th }\end{array}$ & - & 25 & 2 \\
\hline $\begin{array}{c}18-21 \\
\text { th }\end{array}$ & - & 58 & 6 \\
\hline $\begin{array}{c}<21 \\
\text { th }\end{array}$ & - & 11 & - \\
\hline Total & 21 & 168 & 8 \\
\hline
\end{tabular}

Sumber: HUMANA, 2004

Jumlah anak jalanan laki-laki tahun 2004 kurang lebih 300 orang (HUMANA, 2004). Latar belakang anak jalanan di Yogyakarta yang sangat kompleks. Ada beberapa alasan anak turun ke jalan, antara lain: faktor ekonomi keluarga, perceraian orang tua, kekerasan dalam rumah tangga. Permasalahan yang sering dihadapi oleh anak jalanan adalah sulitnya memperoleh: identitas, kesehatan, pendidikan, tempat tinggal yang layak, dan lapangan pekerjaan.

Ada beberapa pihak yang berperan dalam perlindungan terhadap anak jalanan, antara lain sebagai berikut:
Pertama, Lembaga Perlindungan Anak (LPA) DIY, dimana Salah satu upaya yang dilakukan LPA DIY dalam mewujudkan perlindungan hukum atas anak (termasuk anak jalanan) di Yogyakarta adalah melalui pembukaan wacana tentang keberadaan dan kondisi anak jalanan melalui berbagai bentuk sosialisasi, melakukan pendekatanpendekatan untuk siasat / solusi untuk masalah anak jalanan (misalnya: identitas / akta kelahiran mereka), dan mengadakan pelatihan-pelatihan untuk anak jalanan.

Kedua, Lembaga Swadaya Masyarakat (LSM), antara lain: Perkumpulan Keluarga Berencana Indonesia (PKBI) DIY, dimana, Perlindungan anak jalanan yang dilakukan oleh PKBI DIY sangat didukung oleh keberadaan keluarga yang mantap. Upaya yang dilakukan oleh PKBI DIY meliputi upaya preventif (berupa penyuluhan dan pendampingan) dan upaya reprensif (antara lain pemberian konseling), dengan sasaran utamanya adalah anak jalanan perempuan yang sangat rentan terhadap eksploitasi secara ekonomi dan seksual dan lembaga swadaya masyarakat yang lain adalah Rumah Singgah Anak Mandiri, dimana Program Rumah Singgah Anak Mandiri untuk mewujudkan visi dan misinya meliputi: penjangkauan, pendampingan, pemberdayaan, reunifikasi (pemulangan 
kembali anak jalanan kepada keluarganya). Rumah Singgah Anak Mandiri yang dipayungi oleh Yayasan Insan Mandiri adalah sebagai wali dari anak-anak jalanan yang didampingi antara lain: mengurus identitas akta kelahiran atau KTP, izin sekolah, dan sebagainya, serta tetap menjalin kerjasama dengan lembaga lainnya yang berperan di dalam perlindungan anak.

Ketiga, Lembaga Bantuan Hukum (LBH) Yogyakarta, dimana Lembaga Bantuan Hukum (LBH) Yogyakarta memberi bantuan hukum secara cumacuma tanpa membeda-bedakan agama, keturunan, suku, keyakinan politik, maupun latar belakang sosial dan budayanya. Adapun masalah yang sering sekali dihadapi oleh anak-anak jalanan di Yogyakarta ialah penggarukan oleh pihak Keamanan dan Ketertiban (Kamtib) karena tidak memiliki kartu identitas seperti Kartu Tanda Penduduk (KTP). Lembaga Bantuan Hukum (LBH) Yogyakarta telah mengupayakan agar anak-anak jalanan tersebut mendapatkan kartu identitas, sampai muncullah Kartu Identitas Penduduk Musiman (KIPEM) yang juga bermanfaat untuk kelancaran layanan publik bagi anak-anak jalanan tersebut, di samping juga terhindar dari penggarukan oleh pihak Kamtib. Memang masih harus diperjuangkan adanya peraturan yang tidak diskriminatif bagi anak jalanan, selaras dengan Undang-undang Dasar 1945 (khususnya Pasal 27, 28 dan 34) dan Undang-Undang Nomor 39 Tahun 1999 tentang Hak Asasi Manusia (khususnya tentang hak-hak anak).

Semua orang yang belum dewasa/anak ada di bawah kekuasaan orang tuanya atau dibawah perwalian (Pasal 353 KUH Perdata). Berdasarkan Pasal 2 ayat (3) dan (4) Undang-Undang Nomor 4 Tahun 1979 tentang kesejahteraan Anak, maka jelaslah dinyatakan bahwa perlu adanya perlindungan anak dalam rangka mengusahakan kesejahteraan anak dan perlakuan yang adil terhadap anak. Pasal 11 ayat (2) Undang-Undang Nomor 4 Tahun 1979 tentang Kesejahteraan Anak menegaskan bahwa upaya perlindungan anak dilakukan oleh Pemerintah dan atau masyarakat.

Anak dan orang dewasa yang tidak terdaftar serta tidak memiliki akta kelahiran amat rentan terhadap ekspolitasi. Orang yang tidak dapat memperlihatkan akta kelahirannya seringkali kehilangan perlindungan yang diberikan hukum, karena di mata negara secara teknis mereka tidak ada. Pasal 5 Undang-undang Nomor 35 Tahun 2014 tentang Perlindungan Anak yang menyebutkan bahwa setiap anak berhak atas nama sebagai identitas dan 
status kewarganegaraan. Pasal 27 ayat (2) Undang-Undang Nomor 35 Tahun 2014 menjelaskan bahwa identitas dari setiap anak dituangkan dalam akta kelahiran. Kata "setiap" dalam pasal tersebut sebenarnya dengan jelas memiliki maksud bahwa akta kelahiran adalah hak dari semua anak (termasuk anak jalanan sekalipun asal usul mereka tidak jelas), tanpa adanya diskriminasi sesuai dengan aturan yang berlaku. Bahkan pemerintah pun memiliki tanggungjawab dalam perbuatan akta kelahiran untuk setiap anak, sesuai yang diatur Pasal 28 UndangUndang Nomor 35 Tahun 2014 tentang Perlindungan Anak.

Rumah singgah anak jalanan dapat dipandang sebagai Centre based, yakni satu lembaga atau panti yang dikelola secara fleksibel menurut keadaan anak jalanan. Rumah singgah anak anak jalanan merupakan program semi institusional yang bersifat terbuka selama 24 jam untuk anak jalanan, sehingga anak jalanan tidak terikat secara formal, mereka bebas keluar masuk kapanpun mereka mau untuk sekedar berkumpul atau untuk penanganan suatu masalah. Demikian pula dengan keberadaan Rumah Singgah Anak Mandiri di Yogyakarta. Berdasarkan data yang diperoleh dari Rumah Singgah Anak Mandiri yang dipayungi oleh Yayasan Insan Mandiri, maka wujud perlindungan hukum keperdataan yang diperoleh anak jalanan yang menjadi anak dampingannya adalah perwalian. Hal ini diatur dalam Pasal 33 Undang-Undang Nomor 35 Tahun 2014 tentang Perlindungan Anak, yaitu (1) Dalam hal Orang Tua dan Keluarga Anak tidak dapat melaksanakan kewajiban dan tanggung jawab sebagaimana dimaksud dalam Pasal 26, seseorang atau badan hukum yang memenuhi persyaratan dapat ditunjuk sebagai Wali dari Anak yang bersangkutan. (2) Untuk menjadi Wali dari Anak sebagaimana dimaksud pada ayat (1) dilakukan melalui penetapan pengadilan. (3) Wali yang ditunjuk sebagaimana dimaksud pada ayat (2) harus memiliki kesamaan dengan agama yang dianut Anak. (4) Wali sebagaimana dimaksud pada ayat (2) bertanggung jawab terhadap diri Anak dan wajib mengelola harta milik Anak yang bersangkutan untuk kepentingan terbaik bagi Anak.

Ketentuan lebih lanjut mengenai syarat dan tata cara penunjukan Wali sebagaimana dimaksud pada ayat (1) diatur dengan Peraturan Pemerintah.

Di dalam KUH Perdata Buku Kesatu, Bab XV, Bagian Keenam juga diatur tentang perwalian oleh perhimpunanperhimpunan, yayasan-yayasan dan lembaga-lembaga amal. Pendekatan yang dilakukan terhadap anak jalanan adalah pintu masuk untuk rumah singgah 
mengerjakan tanggungjawabnya untuk menjadikan anak jalanan "hidup normatif" sampai kembali kepada keluarganya.

Penerapan sanksi hukum juga diperlukan untuk menghidupkan peraturan perlindungan anak demi terpenuhinya hakhak anak. Oleh karena itu, perlindungan anak jalanan sangat memerlukan jaminan peraturan perundang-undangan yang baik dan tegas; sehingga tercapailah pelaksanaan perlindungan anak jalanan yang rasional (wajar), bertanggung jawab (dapat dipertanggungjawabkan secara horizontal yaitu terhadap orang lain dan diri sendiri, serta vertikal yaitu terhadap Tuhan), dan bermanfaat (bermanfaat untuk orang lain, masyarakat, bangsa dan diri sendiri).

\section{KESIMPULAN}

Berdasarkan analisis mengenai dimensi keperdataan dalam perlindungan hukum atas anak jalanan di Yogyakarta, dapat disimpulkan bahwa anak jalanan di Yogyakarta masih belum terlindungi pemenuhan hak-haknya terutama dalam perlindungan hukum keperdataannya. Fenomena anak jalanan di Yogyakarta yang cukup kompleks dan memiliki mobilitas yang terus berfluktuasi dilatar belakangi oleh beberapa faktor, antara lain: faktor ekonomi keluarga, perceraian orang tua, dan kekerasan dalam rumah tangga.
Permasalahan yang sering dihadapi oleh anak jalanan di Yogyakarta adalah sulitnya memperoleh: identitas, kesehatan, pendidikan, tempat tinggal yang layak, dan pekerjaan. Budaya masyarakat Yogyakarta yang menganggap anak sebagai "asset" orang tua dan rendahnya tingkat pendidikan juga mempengaruhi pelaksanaan perlindungan anak jalanan di Yogyakarta, antara lain: Lembaga Perlindungan Anka (LPA) DIY, Perkumpulan Keluarga Berencana Indonesia(PKBI) DIY, Rumah Singgah Anak Mandiri, Lembaga Bantuan Hukum (LBH) Yogyakarta. Kerjasama dan koordinasi diantara para pihak tersebut, didukung sosialisasi dan penegakan hukum perlindungan anak secara efektif dan tegas sangat diperlukan dalam melancarkan kegiatan perlindungan anak jalanan yang rasional, bertanggung jawab dan bermanfaat. Upaya pendampingan, pembinaan, sampai pada pemulangan kembali (reunifikasi) anak jalanan kepada keluarganya memerlukan kemantapan peran serta terpadu dan sinergi diantara keluarganya memerlukan kemantapan peran serta terpadu dan sinergi diantara keluarga, masyarakat, pemerintah, dan anak jalanan sendiri. 


\section{DAFTAR PUSTAKA}

Soeaidy, Sholeh dan Zulkhair. Dasar Hukum Perlindungan Anak. Jakarta, Novindo Pustaka Mandiri, 2001.

Soekarto, Soerjono. Pengantar Penelitian Hukum, Jakarta: Universitas Indonesia Press, 1984.

Sudrajat, Tata. Anak Jalanan dan Masalah Sehari-hari Sampai Kebijaksanaan, Bandung: Yayasan Akatiga, 1984.

Undang-Undang Dasar Negara Republik Indonesia Tahun 1945
Konvensi Hak Anak Tahun 1989

Kitab Undang-Undang Hukum Perdata (KUH Perdata).

Undang-Undang Nomor 4 Tahun 1979 Tentang Kesejahteraan Anak.

Undang-Undang Nomor 39 Tahun 1999 Tentang Hak Asasi Manusia.

Undang-Undang Nomor 35 tahun 2014 tentang pengganti Undang-Undang Nomor 23 Tahun 2002 Tentang Perlindungan Anak. 